\title{
GAMBARAN PENGETAHUAN KESEHATAN GIGI DENGAN PENYULUHAN METODE STORYTELLING PADA SISWA KELAS III DAN IV SD INPRES MANGASA GOWA
}

\author{
Pariati $^{(1)}$, Jumriani(2) \\ STIKES Amanah Makassar ${ }^{(1)}$, Poltekkes Kemenkes Makassar ${ }^{(2)}$
}

\section{ABSTRAK}

Kesehatan merupakan hak asasi manusia dan salah satu unsur kesejahteraan yang harus diwujudkan sesuai dengan cita-cita bangsa Indonesia. Kesehatan gigi dan mulut memiliki peran penting dalam fungsi bicara, pengunyahan, dan rasa percaya diri. Oleh karena itu kebersihan gigi dan mulut yang harus dijaga sebaik-baiknya. Salah satu penyebab timbulnya masalah kesehatan gigi dan mulut adalah fakor perilaku yang didasari oleh kurangnya pengetahuan akan pemeliharaan kesehatan gigi dan mulut yang akan meningkatkan insidensi penyakit gigi dan mulut di usia dini. Berdasarkan survey awal di SD Inpres Mangasa Gowa, kelas I - VI ternyata kelas III dan IV mempunyai kesehatan gigi yang buruk. Tujuan penelitian ini untuk mengetahui pengetahuan kesehatan gigi sebelum dan sesudah penyuluhan dengan metode storytelling. Jenis penelitian bersifat deskriptif dengan metode storytelling. Sampel penelitian adalah III dan IV SD yang berjumlah 49 orang. Hasil Penelitian yaitu pengetahuan kesehatan gigi sebelum dilakukan penyuluhan dengan metode strorytelling pada kelas III dan IV mempunyai kategori pengetahuan yang sama, yakni kategori sedang, sedangkan setelah dilakukan penyuluhan dengan metode strotytelling mempunyai pengetahuan yang sama pula yakni kategori baik.

Kata Kunci: Kesehatan Gigi, Penyuluhan, Storytelling

\section{PENDAHULUAN}

Kesehatan merupakan hak asasi manusia dan salah satu unsur kesejahteraan yang harus diwujudkan sesuai dengan citacita bangsa Indonesia sebagaimana dimaksud dalam Pancasila dan undangundang dasar republik Indonesia tahun 1945.

Bahwa kegiatan dalam upaya untuk memelihara dan meningkatkan derajat kesehatan masyarakat yang setinggitingginya dilandaskan berdasarkan nondiskriminatif, partisipatif, dan berkelanjutan dalam rangka pembentukan sumber daya manusia Indonesia, serta peningkatan ketahanan dan daya saing bangsa bagi pembangunan nasional (UUD 1945).

Kesehatan gigi dan mulut memiliki peran penting dalam fungsi bicara, pengunyahan, dan rasa percaya diri; oleh karena itu kebersihan gigi dan mulut yang harus di jaga sebaik-baiknya. Efek dari kebersihan gigi dan mulut yang tidak di jaga adalah karies gigi, penyakit periodontal dan sebagainya (Iriana, 2018).

Salah satu penyebab timbulnya masalah kesehatan gigi dan mulut adalah faKtor perilaku yang didasari oleh kurangnya pengetahuan akan pemeliharaan kesehatan gigi dan mulut yang akan meningkatkan insiden sipenyakit gigi dan mulut di usia dini. Menurut teori Bloom, Selain factor perilaku dan faktor lingkungan, keturunan dan pelayanan fasilitas kesehatan juga merupakan faktor yang mempengaruhi status kesehatan manusia termasuk kesehatan gigi dan mulut. (Azhari, 2017).

Berdasarkan survey awal di SD Inpres Mangasa Gowa, dari kelas 1-6 ternyata didapat kelas III dan IV ternyata mempunyai pengetahuan yang kurang tentang kesehatan gigi.

Notoatmodjo (2015) menyatakan bahwa pengetahuan merupakan hasil dari pengindraan manusia, atau hasil tahu seseorang terhadap objek melalui indra yang 
dimilikinya (mata, hidung, telinga, dan sebagainya).

Tingkat pengetahuan Menurut Notoatmodjo (2015) Pengetahuan atau kognitif merupakan domain yang sangat penting untuk terbentuknya tindakan seseorang.

Perilaku kognitif diklasifikasikan dalam urutan hirarki, yaitu:

1) Tahu (know) merupakan tingkat pengetahuan yang paling rendah, karena pada tingkat ini seseorang hanya mampu melakukan recall (mengulang) memori yang telah ada sebelumnya setelah mengamati sesuatu.

2) Memahami (comprehension) dapat diartikan suatu kemampuan untuk menjelaskan suatu objek dan dapat menginterpretasikannya secara benar. Orang yang sudah memahami harus dapat menjelaskan, menguraikan, menyebutkan contoh, dan menyimpulkan.

3) Aplikasi (application) merupakan kemampuan dimana seseorang telah memahami suatu objek, dapat menjelaskan dan dapat mengaplikasikan prinsip yang diketahui meskipun pada situasi yang berbeda.

4) Analisis (analysis) merupakan kemapuan seseorang untuk menggunakan ide-ide abstrak yang baru dipelajari untuk diterapkan dalam situasi nyata. Sehingga dapat menggambarkan atau memecahkan suatu masalah.

5) Sintesis (synthesis) merupakan kemampuan untuk merangkum komponen- komponen dari suatu formulasi yang ada dan meletakkannya dalam suatu hubungan yang logis, sehingga tersusun suatu formula baru.
6) Evaluasi (evaluation) berkaitan dengan kemampuan untuk melakukan penilaian terhadap suatu materi atau objek, yang didasarkan pada suatu kriteria yang telah dibuat sendiri atau menggunakan kriteriakriteria yang telah ada.

Faktor- faktor yang mempengaruhi pengetahuan menurut Mubarak (2015) ada tujuh faktor-faktor yang mempengaruhi pengetahuan seseorang, yaitu:

1) Pendidikan

Pendidikan berarti bimbingan yang diberikan seseorang kepada orang lain terhadap suatu hal agar mereka dapat memahami. Tidak dapat dipungkiri bahwa makin tinggi pendidikan seseorang semakin mudah pula mereka menerima informasi, dan pada akhirnya makin banyak pula pengetahuan yang dimilikinya. Sebaliknya, jika seseorang tingkat pendidikannya rendah, akan menghambat perkembangan sikap seseorang terhadap penerimaan informasi dan nilai-nilai baru diperkenalkan.

2) Pekerjaan

Lingkungan pekerjaan dapat menjadikan seseorang memperoleh pengalaman dan pengetahuan baik secara langsung maupun tidak langsung

3) Umur

Dengan bertambahnya umur seseorang akan terjadi perubahan pada aspek psikis dan psikologis (mental). Pertumbuhan fisik secara garis besar ada empat kategori perubahan, yaitu perubahan ukuran, perubahan proporsi, 
hilangnya ciri-ciri lama dan timbulnya ciri-ciri baru.

4) Minat

Sebagai suatu kecenderungan atau keinginan yang tinggi terhadap sesuatu. Minat menjadikan seseorang untuk mencoba dan menekuni suatu hal dan pada akhirnya diperoleh pengetahuan yang lebih dalam.

5) Pengalaman

Suatu kejadian yang pernah dialami seseorang dalam berinteraksi dengan lingkungannya. Ada kecenderungan pengalaman yang baik seseorang akan berusaha untuk melupakan, namun jika pengalaman terhadap objek tersebut menyenangkan maka secara psikologis akan timbul kesan yang membekas dalam emosi sehingga menimbulkan sikap positif.

6) Kebudayaan

Kebudayaan lingkungan sekitar, apabila dalam suatu wilayah mempunyai budaya untuk menjaga kebersihan lingkungan maka sangat mungkin masyarakat sekitarnya mempunyai sikap untuk selalu menjaga kebersihan lingkungan.

\section{Kesehatan gigi}

Gigi yang sehat adalah gigi yang bersih tanpa ada lubang atau penyakit gigi Lainnya. Dengan memiliki gigi dan mulut yang sehat, beberapa aktifitas seperti berbicara, tidur, makan dan bersosialisasi tidak akan terganggu karena terhindar dari rasa sakit, tidak nyaman dan malu.

Perawatan gigi merupakan usaha penjagaan untuk mencegah kerusakan gigi dan penyakit gusi. Perawatan gigi sangat penting dilakukan karena dapat menyebabkan rasa sakit pada anak, infeksi, bahkan malnutrisi. Gigi yang sehat adalah gigi yang bersih tanpa ada lubang atau penyakit gigilainnya. Tan dalam Houwink, et al (2015) mengatakan perawatan gigi yang dapat dilakukan untuk mencegah masalah kesehatan gigi antara lain:

\section{Pendidikan Kesehatan Gigi}

Pendidikan Kesehatan Gigi

merupakan suatu proses pendidikan yang timbul atas dasar kebutuhan kesehatan gigi dan mulut yang bertujuan untuk menghasilkan kesehatan gigi dan mulut yang baik dan meningkatkan taraf hidup. Dalam proses pendidikan termasuk pendidikan kesehatan gigi dan mulut, individu memperoleh pengalaman atau pengetahuan melalui berbagai media pendidikan (Suiraoka, 2012 dalam Andi, 2018).

Mengubah perilaku individu bukanlah merupakan pekerjaan yang mudah, dalam hal ini dibutuhkan keterampilan khusus sebab perubahan tingkah laku individu selalu melibatkan perubahan mental. Perubahan itu sendiri terjadi secara alamiah yaitu karena lingkungan atau masyarakat sekitarnya. Namun, ada pula perubahan yang terjadi secara terencana dan dilaksanakan secara sistematis, yaitu yang dikenal sebagai perubahan melalui pendidikan.

\section{Metode StoryTelling}

Moeslichatoen (2016) menyatakan bahwa metode bercerita merupakan salah satu pemberian pengalaman belajar bagi anak Taman kanak-kanak dengan membawakan cerita kepada anak secara lisan. Cerita yang dibawakan oleh guru atau tenaga kesehatan harus menarik dan 
mengundang perhatian anak dan tidak lepas dari tujuan pendidikan bagi anak- anak.

Sanders (dalam Musfiroh, 2015) mengemukakan bahwa ada beberapa alasan penting mengapa anak perlu mendengarkan cerita. Salah satunya karena mendengarkan cerita merupakan sesuatu yang menyenangkan bagi anak.

Moeslichatoen (2017) menjelaskan bahwa ada beberapa macam teknik bercerita yang dapat dipergunakan antara lain guru dapat membaca langsung dari buku, menggunakan ilustrasi dari buku gambar, menggunakanpapan flanel, menggunakan boneka, serta bermain peran dalam satu cerita.

\section{METODOLOGI PENELITIAN}

Jenis penelitian ini bersifat deskriptif untuk mengetahui efektifitas penyuluhan dengan metode storytelling untuk meningkatkan pengetahuan kesehatan gigi dan mulut pada siswa. Penelitian ini akan laksanakan di SD Inpres Mangasa Gowa pada bulan Juni sampai Juli 2019.
Populasi dalam penelitian ini adalah seluruh siswa di SD Inpres Mangasa Gowa yang berjumlah 146 siswa dengan sampel yaitu Kelas I dan II SD inpres mangasa Gowa yang berjumlah 49 orang yang dilakukan dengan teknik sampling di mana peneliti mengambil sampel sesuai kebutuhan penelitian.

Pengetahuan Kesehatan gigi sebelum dan sesudah dilakukan penyuluhan dengan menggunakan metode storytelling di hitung dengan cara memberi setiap jawaban benar dengan skor 10, dan jawaban yang salah mendapatkan skor 0, Dengan kategori Baik jika 76\%-100\%, Sedang 56\%-75\%, Kurang $\quad 0 \%-55 \%$. Kemudian seluruh kuisioner dihitung dengan menggunakan rumus kuesioner (Arikunto):

$$
\mathrm{P}=\frac{\sum \mathrm{F}}{N} \mathrm{X} 100 \%
$$

Keterangan:

$\mathrm{P} \quad=$ Nilai pengetahuan

$\Sigma F=$ Jumlah jawaban yang benar

$\mathrm{N}=$ Jumlah pertanyaan

\section{HASIL PENELITIAN}

Tabel 1. Distribusi Siswa Berdasarkan Jenis Kelamin di SD Inpres Mangasa Gowa Kelas III dan IV

\begin{tabular}{|c|c|c|}
\hline Jenis kelamin & Jumlah & Persentase (\%) \\
\hline Laki - Laki & 44 & 67,7 \\
\hline Perempuan & 21 & 32,5 \\
\hline Total & 65 & 100 \\
\hline
\end{tabular}

Tabel 1 di atas, dapat diketahui bahwa mayoritas responden berjenis kelamin laki-laki sebanyak 44 anak (67,7\%). Sisanya berjenis kelamin perempuan sebanyak 21 anak $(32,5 \%)$. 
Tabel 2. Distribusi Pengetahuan Kesehatan Gigi sebelum Penyuluhan Dengan Metode StoryTelling pada siswa kelas III

\begin{tabular}{|c|c|c|}
\hline Tingkat pengetahuan & Jumlah & Persentase (\%) \\
\hline Baik & 2 & 6,25 \\
\hline Sedang & 19 & 59,3 \\
\hline Buruk & 11 & 34,3 \\
\hline Total & 32 & 100 \\
\hline
\end{tabular}

Dari tabel 2 dapat dilihat bahwa pengetahuan siswa melalui pre- test terbanyak adalah siswa yang pengetahuannya sedang dengan siswa berjumlah $19(59,3 \%)$, diikuti dengan siswa yang berpengetahuan buruk berjumlah 11 siswa (34, $3 \%)$, dan siswa yang berpengetahuan baik berjumlah 2 siswa $(6,25 \%)$.

Tabel 3. Distribusi Pengetahuan Kesehatan Gigi Setelah Pendidikan Kesehatan Gigi Dengan Metode StoryTelling pada siswa kelas III

\begin{tabular}{|c|c|c|}
\hline Tingkat pengetahuan & Frekuensi & Persentase (\%) \\
\hline Baik & 24 & 75,0 \\
\hline Sedang & 6 & 18,7 \\
\hline Buruk & 2 & 6,25 \\
\hline Total & 32 & 100 \\
\hline
\end{tabular}

Dari tabel 3 dapat dilihat bahwa pengetahuan siswa melalui post test yang terbanyak adalah siswa dengan pengetahuan baik berjumlah 24 siswa (75
$\%$, diikuti dengan siswa yang pengetahuan sedang berjumlah 6 siswa $(18,7 \%)$, dan siswa yang pengetahuan buruk dengan jumlah siswa 2 (6,25\%).

Tabel 4. Distribusi Pengetahuan Kesehatan Gigi Sebelum Penyuluhan Dengan Metode StoryTelling pada siswa kelas IV

\begin{tabular}{|c|c|c|}
\hline Pengetahuan & Jumlah & Persentase (\%) \\
\hline Baik & 3 & 9,09 \\
\hline Sedang & 20 & 60,6 \\
\hline Buruk & 10 & 30,5 \\
\hline Total & 33 & 100 \\
\hline
\end{tabular}

Dari tabel 4 dapat dilihat bahwa pengetahuan siswa melalui pre test yang terbanyak adalah siswa dengan pengetahuan sedang berjumlah 20 siswa
$(60,6 \%)$, diikuti dengan siswa yang pengetahuan buruk berjumlah 10 siswa $(30,5 \%)$, dan siswa yang pengetahuan baik dengan berjumlah 3 siswa $(9,09 \%)$. 
Tabel 5. Distribusi Pengetahuan Kesehatan Gigi Setelah Penyuluhan Dengan Metode StoryTelling pada siswa kelas IV

\begin{tabular}{|c|c|c|}
\hline Tingkat pengetahuan & Jumlah & Persentase (\%) \\
\hline Baik & 26 & 78,7 \\
\hline Sedang & 7 & 21,2 \\
\hline Buruk & 0 & 0 \\
\hline Total & 33 & 100 \\
\hline
\end{tabular}

Dari tabel 5 dapat dilihat bahwa pengetahuan siswa melalui post test yang terbanyak adalah siswa dengan pengetahuan baik berjumlah 26 siswa

\section{PEMBAHASAN}

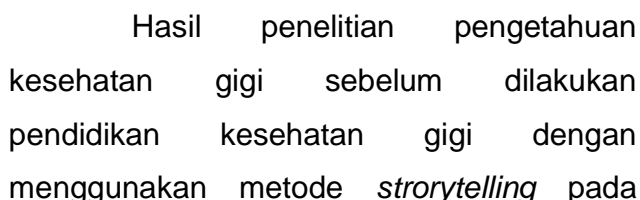
kelas III dan IV mempunyai kategori pengetahuan yang sama, yakni kategori sedang, sedangkan setelah dilakukan pendidikan kesehatan gigi dengaan menggunakan metode strotytelling mempunyai pengetahuan yang sama pula yakni kategori baik. Artinya terjadi peningkatan pengetahuan kesehatan gigi dan mulut pada responden sebelum dan setelah diberikan pendidikan kesehatan gigi dengan menggunakan metode storytelling.

$$
\text { Penelitian ini didukung oleh }
$$
penelitian Soekidjo Notoatmodjo (2012) menyimpulkan bahwa adanya peningkatan pengetahuan kesehatan gigi dan mulut setelah dilakukan penyuluhan dengan metode storytelling.

Hasil penelitian oleh Sinor (2011) juga sangat mendukung dengan penelitian ini yang menyatakan bahwa metode storytelling adalah metode yang lebih efektif dalam menyampaikan pesan pendidikan
(78,8\%), diikuti dengan siswa yang pengetahuan sedang berjumlah 7 siswa $(30,5 \%)$, dan siswa tidak ada siswa yang memiliki pengetahuan buruk.

kesehatan mulut dibandingkan dengan metode konvensional pada siswa di sekolah Hulu Terengganu District.

\section{KESIMPULAN}

1. Pengetahuan kesehatan gigi dan mulut pada siswa kelas III dan IV SD Inpres Mangasa Gowa sebelum dilakukan pendidikan kesehatan gigi dengan menggunakan metode stroeytelling mempunyai kategori yang sama yakni sedang dengan jumlah kelas III sebanyak 59,3 \% dan kelas IV Sebanyak 60,6\%.

2. Pengetahuan kesehatan gigi dan mulut pada siswa kelas III dan IV SD Inpres Mangasa Gowa setelah dilakukan pendidikan kesehatan gigi dengan menggunakan metode stroeytelling mempunyai kategori yang sama yakni baik dengan jumlah kelas III sebanyak $75,0 \%$ dan kelas IV sebanyak 78,7\%.

\section{SARAN}

Diharapkan bagi pihak sekolah terkait dapat bekerja sama dengan parah petugas kesehatan gigi sekolah (UKGS) 
dalam upaya meningkatkan derajat kesehatan gigi anak secara

berkesinambungan.

\section{DAFTAR PUSTAKA}

Amir A.B,2018,"efektifitas pendidikan kesehatan gigi dengan metode dongeng dan peta pemikiran terhadap pengetahan kesehatan gigi pada siswa SDN menggarmas 1 grobongan"[KTI] Politeknik kesehatan Semarang.

Aprilahz I, 2016, "Perbandingan Efektifitas Antara Metode Vidio dan Cerita Boneka Dalam Pendidikan Seksual Terhadap Pengetahuan Anak Prasekolah" [Skripsi] Universitas Islam Negeri Syarif Hidayatullah 2016.

Arifah A.N, 2016, "Hubungan Pengetahuan, Sikap dan Tindakan Kesehatan Gigi dan Mulut Terhadap Status Kesehatan Gigi Pelajar SMP/MTS Pondok Pesantren Ummul Mukminin" [Skripsi] Universitas Hasanuddin 2016.

Asnawiyah R, 2014 "Efektifitas Bercerita Terhadap Peningkatan Pengetahuan Dalam Penyuluhan Perilaku Hidup Bersih dan Sehat" Jurnal Promosi Kesehatan Vol. 2 No.2. 2014.

Dani, D.E. (2013) "Pembentukan Karakter Anak Melalui Kegiatan Mendongeng." Redaksi Jurnal HUMANIKA, 17:91.

Diyatama A, dkk, 2016, "Gambaran Penyuluhan Tentang Pengetahuan
Kesehatan Gigi dan Mulut Dengan Metode Bercerita Wayang Kartun Untuk Meningkatkan Pengetahuan Siswa SD" Jurnal Gigi Dan Mulut Vol. 3 No.2 POLTEKES KEMENKES Jogjakarta.

Hartanti D, 2016, "Perbedaan Pengaruh Metode Cerita dan Poster Terhadap Peningkatan Pengetahuan Siswa Tentang Cara Perawatan Gigi di Paud Pertiwi dan Ardika Jaya Bekasi" [Skripsi] Fakultas Kedokteran dan IImu Kesehatan Universitas islam Syarif Hidayatullah.

Pratiwi D, 2016, "Pengaruh Metode Storytelling Terhadap Perilaku Menggosok Gigi di TK Dharma Wanita IV Banjar Sengon Kabupaten Jember" [Skripsi] Universitas Jember.

Prihmantoro A.D, Dkk, 2017, "Pengaruh Pendidikan Kesehatan Gigi dengan Metode Bermain (bercerita) Terhadap Perilaku Menggosok Gigi Pada Anak Prasekolah" Jurnal Global Health Science Vol. 2 Issue.2 2017.

Rhamadan. 2016. "Hubungan Tingkat Pengetahuan Kesehatan Gigi dan Mulut Terhadap Angka Karies Gigi Di Smpn 1 Marabahan". Dentino, Vol.1 No.2.

Widasari, R.H. (2012) "Hubungan

Penguasaan Kosakata dengan Keterampilan Bercerita Siswa Kelas 5 SD seKecamatan Wonosari Kabupaten Gunung Kidur'. Skripsi. Yogyakarta: FIP UN. 